\title{
HUBUNGAN MOTIVASI BELAJAR TERHADAP MINAT BELAJAR PADA MAHASISWA TINGKAT II DI AKADEMI KEPERAWATAN PANTI KOSALA SURAKARTA
}

\author{
Oleh : \\ Endang Dwi Ningsih ${ }^{1}$ Rahayu Setyaningsih ${ }^{2}$ Vitha Vidianingrum ${ }^{3}$
}

\begin{abstract}
Background Motivation is an important role in learning. Motivation empower someone doing activities and it has related with the learning interest.

According to the writers observation at the Panti Kosala Nursing Academy Surakarta students, shows that the students have not interested in the learning process which is unparallel with the class attendance performance $100 \%$.

Base on the observation, a research done on the second level students of the Panti Kosala Nursing Academy Surakarta.

The aim is to know the relation between learning motivation and learning interest of the students.

The kind of research was analitical. The research design, correlation and Cross-section approach.

The subject were the 97 second level students of the Panti Kosala Nursing Academy Surakarta.

The result data were analyzed by Chi-square with $P=0,05$; $P$ value got : $0,000<P=0,05$ indicate the Ha value available received (acceptable).

The conclusion is having a relation between learning motivation and learning interest on the second level student of the Panti Kosala Nursing Academy Surakarta.
\end{abstract}

Keywords: Motivation and Learning interest

\section{PENDAHULUAN}

Motivasi mempunyai peranan penting dalam kegiatan belajar. Motivasi adalah tenaga yang menggerakkan dan mengarahkan aktivitas seseorang. Motivasi mempunyai kaitan yang erat dengan minat. Siswa yang memiliki minat terhadap suatu bidang studi tertentu cenderung tertarik perhatiannya dan dengan demikian timbul motivasinya untuk mempelajari bidang studi tersebut.(Dimyati dan Mudjiono, 2006)

Minat belajar besar sekali pengaruhnya terhadap hasil belajar sebab dengan minat seseorang akan melakukan sesuatu yang diminatinya. Sebaliknya tanpa minat seseorang tidak mungkin melakukan sesuatu. Misalnya seorang anak menaruh minat terhadap bidang kesenian, maka ia akan berusaha untuk mengetahui lebih banyak tentang kesenian. (Sukasni, 2011)

Minat adalah perasaan tertarik dan keterkaitan pada sesuatu hal atau aktifitas tanpa ada yang menyuruh. Minat pada dasarnya adalah penerimaan suatu hubungan antara diri sendiri dengan sesuatu diluar dirinya. Disadari atau tidak disadari dunia pendidikan pada saat ini khususnya di Indonesia mengalami masalah antara lain menurunnya kualitas pendidikan dan mutu pendidikan yang masih rendah. Oleh karena itu menurunnya kualitas pendidikan merupakan tanggung jawab bersama. Pendidik perlu 
memadukan antara faktor lingkungan dengan faktor alami peserta didik atau faktor dari dalam diri dengan faktor dari luar peserta didik. Faktor dari dalam diri siswa dapat dipengaruhi oleh motivasi belajar, dan membaca, motivasi diri, kecerdasan dan intelektual. Sedangkan faktor dari luar siswa dapat dipengaruhi oleh motivasi dari guru, metode pembelajaran, model pembelajaran, dan media pembelajaran. Sedangkan minat harus dimunculkan dari kesadaran sendiri untuk tertarik pada motivasi aktifitas yang akan dilakukan. (Sukasni, 2011)

Pada pengamatan penulis di Akademi Keperawatan Panti Kosala Surakarta menunjukkan bahwa masalah yang terjadi dalam proses belajar-mengajar terutama yang berhubungan dengan minat dan motivasi belajar, mahasiswa tidak berminat terhadap mata kuliah dan dosen pengajaran tertentu. Tidak sedikit mahasiswa hanya sekedar hadir untuk mentaati peraturan kehadiran yang ada dan hanya tidur maupun sekedar rmengobrol di dalam kelas bersama temantemannya. Beberapa dosen juga berpendapat bahwa mahasiswa dalam proses belajar-mengajar tidak bersemangat dalam mengikuti perkuliahan, mahasiswa cenderung pasif dalam proses belajar-mengajar. Dalam mengerjakan tugas mahasiswa asal mengerjakan, tidak tepat waktu dalam mengumpulkan bahkan tidak mengerjakan sama sekali.

Tujuan umum penelitian ini adalah untuk mengetahui hubungan antara motivasi belajar dengan minat belajar pada mahasiswa tingkat II Akademi KeperawatanPanti Kosala Surakarta.

\section{METODE PENELITIAN}

Rancangan penelitian yang peneliti gunakan adalah rancangan penelitian korelasional. Jenis rancangan korelasional bertujuan untuk mendapatkan gambaran tentang hubungan antara dua atau lebih variabel penelitian. Dengan diketahuinya hubungan variabel tersebut maka peneliti dapat menarik kesimpulan dari permasalahan yang diteliti. Teknik pendekatan yang digunakan adalah cross sectional yaitu data yang dikumpulkan sesaat atau data saat ini juga. Cara ini dilakukan dengan melakukan survey, wawancara atau dengan menyebarkan kuesioner pada responden peneliti. (Suyanto, 2011) Tujuan penelitian korelasi ini adalah untuk mengetahui hubungan antara motivasi belajar sebagai variabel bebas dan minat belajar sebagai variabel terikat yang akan dipengaruhi oleh variabel pengganggu yaitu siswa, guru, sistem sekolah, dan keadaan situasional.

Dalam penelitian ini peneliti mengambil sampel sesuai dengan populasi yang ada yaitu sebanyak 30 mahasiswa. Teknik sampling yang digunakan dalam pengambilan sampel pada penelitian ini menggunakan simple random sampling yaitu pengambilan sampel dengan cara acak tanpa memperhatikan strata yang ada dalam populasi.

Pengumpulan data yang dilakukan adalah dengan cara responden diberi lembar kuesioner tentang motivasi belajar dan minat belajar serta dijelaskan tentang cara mengisi kuesioner. Setelah responden selesai mengisi, maka peneliti memeriksa kelengkapan lembar kuesioner.

\section{HASIL PENELITIAN}

Penelitian dilaksanakan pada tanggal 13 Januari sampai dengan 2 Februari 
2014 di Kampus Akademi Keperawatan Panti Kosala Surakarta dengan jumlah responden sebanyak 97 mahasiswa tingkat II Akper Panti Kosala Surakarta.

1. Motivasi Belajar

Tabel 1.1 Distribusi Frekuensi Motivasi belajar

\begin{tabular}{|c|c|c|}
\hline $\begin{array}{c}\text { Motivasi } \\
\text { Belajar }\end{array}$ & Frekuensi & $\%$ \\
\hline Tinggi & 47 & 48,45 \\
\hline Sedang & 48 & 49,48 \\
\hline Rendah & 2 & 2,06 \\
\hline Jumlah & 97 & 100 \\
\hline
\end{tabular}

Tabel 1.2 Hasil Analisa univariat Motivasi belajar

\begin{tabular}{|c|c|}
\hline Analisa univariat & Hasil \\
\hline Mean & 13,40 \\
\hline Median & 13 \\
\hline Modus & 13 \\
\hline
\end{tabular}

2. Minat belajar

Tabel 2.1 Distribusi Frekuensi Minati belajar

\begin{tabular}{|c|c|c|}
\hline $\begin{array}{c}\text { Minat } \\
\text { Belajar }\end{array}$ & Frekuensi & $\%$ \\
\hline Tinggi & 45 & 46,39 \\
\hline Sedang & 49 & 50,52 \\
\hline Rendah & 3 & 3,09 \\
\hline Jumlah & 97 & 100 \\
\hline
\end{tabular}

Tabel 2.2 Hasil Analisa univariat Motivasi belajar

\begin{tabular}{|c|c|}
\hline Analisa Univariat & Hasil \\
\hline Mean & 12,56 \\
\hline Median & 13 \\
\hline Modus & 15 \\
\hline
\end{tabular}

3. Hubungan antara motivasi belajar

Tabel 3.1 Hubungan antara motivasi belajar

\begin{tabular}{|c|c|c|c|c|}
\hline Motivasi & \multicolumn{3}{|c|}{ Minat Belajar } & \multirow{2}{*}{ Jml } \\
\cline { 2 - 5 } Belajar & Rendah & Sedang & Tinggi & \\
\hline Rendah & 1 & 1 & 0 & 2 \\
\hline Sedang & 2 & 33 & 13 & 48 \\
\hline Tinggi & 0 & 14 & 33 & 47 \\
\hline Jumlah & 3 & 48 & 46 & 97 \\
\hline
\end{tabular}

4. Analisa bivariat

Berdasarkan hasil uji Chi Square didapatkan hasil $p=0,00$ (probabilitas $<0,05$ ) sehingga $\mathrm{Ha}$ diterima, yang berarti ada hubungan yang signifikan antara motivasi belajar dengan minat belajar pada mahasiswa tingkat II di Akper Panti Kosala Surakarta, karena besarnya hubungan 0,866 atau $86,6 \%$ dilihat dari nilai contingency coefficient.

\section{PEMBAHASAN}

1. Motivasi Belajar

Terdapat 47 responden $(48,45 \%)$ mempunyai motivasi belajar yang tinggi, 48 responden $\quad(49,48 \%)$ mempunyai motivasi belajar yang sedang, dan 2 responden $(2,06 \%)$ mempunyai motivasi belajar yang rendah.

Didapatkan nilai mean sebesar 13,40, nilai tengah sebesar 13, dan nilai yang paling banyak muncul adalah nilai 13 , hal ini menunjukkan mean, median, dan modus motivasi belajar berada pada kategori tinggi.

Motivasi artinya mendorong seseorang untuk berbuat atau beraksi. Menurut Stevenson (2001), sebagaimana dikutip oleh Sunaryo (2004), motivasi adalah semua hal verbal, fisik, atau psikologis yang membuat seseorang melakukan sesuatu sebagai respon. Dari definisi di atas maka dapat penulis 
kemukakan bahwa motivasi belajar yang tinggi pada mahasiswa Akper Panti Kosala karena adanya hal verbal, fisik atau psikologis yang membuat mahasiswa Akper Panti Kosala melakukan sesuatu, berarti fasilitas fisik dan non fisik Akper Panti Kosala memadai, sehingga menjadikan mahasiswa termotivasi dengan baik.

Sebagaimana yang diungkapkan oleh Dimyati dan Mudjiono (2006), beberapa unsur yang mempengaruhi motivasi belajar diantaranya cita-cita, kemampuan, kondisi orangnya, kondisi lingkungan, unsur-unsur dinamis dalam belajar dan upaya guru dalam membelajarkan mahasiswa.

Dari unsur-unsur tersebut, dapat diamati oleh penulis, bahwa Akper Panti Kosala berjuang untuk menggabungkan unsurunsur tersebut semaksimal mungkin. Ada kemungkinan cita-cita, kondisi mahasiswa dan kemampuan mahasiswa tidak mampu untuk diproses sesuai situasi belajar yang ditetapkan, maka Akper Panti Kosala memaksimalkan unsur lingkungan, unsur-unsur yang dinamis dalam belajar, dan upaya-upaya untuk memaksimalkan kemampuan belajar mahasiswa dengan cara keras, bujukan ataupun identifikasi sebagaimana yang diungkapkan Sunaryo (2004), bahwa cara-cara seseorang yang dapat diterapkan untuk memotivasi seseorang adalah memotivasi dengan kekerasan (motivating by force), yaitu cara memotivasi dengan menggunakan ancaman hukuman atau kekerasan agar yang dimotivasi dapat melakukan apa yang harus dilakukan, memotivasi dengan bujukan (motivating by enticement), yaitu cara memotivasi dengan bujukan atau memberi hadiah agar melakukan sesuatu harapan yang memberikan motivasi, dan memotivasi dengan mengidentifikasi (motivating by indentification or egoivolvement), yaitu cara memotivasi dengan menanamkan kesadaran sehingga individu berbuat sesuatu karena adanya keinginan yang timbul dari dalam dirinya sendiri dalam mencapai sesuatu.

\section{Minat Belajar}

Pada penelitian ini ditemukan 3 responden $(3,09 \%)$ mempunyai minat belajar rendah, 48 responden $\quad(49,48 \%)$ mempunyai minat belajar sedang, 46 responden $(47,42 \%)$ mempunyai minat belajar tinggi. Didapatkan nilai mean sebesar 12,56 , nilai sebesar 13 , dan nilai yang sering muncul adalah nilai 15, hal ini menunjukkan bahwa mean, median, dan modus untuk minat belajar pada kategori tinggi.

Dari data di atas maka dapat disimpulkan bahwa minat belajar mahasiswa Akper Panti Kosala dikategorikan tinggi. Sebagaimana yang diungkapkan oleh Purwanto (1998) bahwa minat merupakan kekuatan dari dalam dan tampak dari luar sebagai gerakgerik. Hal ini dapat dilihat pada kegiatan-kegiatan belajar mahasiswa Akper Panti Kosala yang intensitasnya sangat tinggi didalam beraktifitas menyelesaikan tugas-tugas belajar antara lain dengan mengikuti kuliah, mengerjakan tugas-tugas, mengikuti bimbingan dosen, dan kegiatan- 
kegiatan lain yang berkaitan dengan aktifitas pembelajaran.

3. Hubungan antara Motivasi Belajar dengan Minat Belajar Dari data terdapat 47 responden $\quad(48,45 \%)$ mempunyai motivasi belajar yang tinggi dengan minat belajar tinggi 33 orang dan minat belajar sedang 14 orang, 48 responden $\quad(49,48 \%)$ mempunyai motivasi belajar yang sedang dengan minat belajar tinggi 13 orang dan dengan minat belajar sedang 33 orang, dan 2 responden (2,06\%) mempunyai motivasi belajar yang rendah. Dengan minat belajar rendah 1 orang dan minat belajar sedang 1 orang dan nampak pada tabel bila motivasi rendah, minat juga rendah, bila motivasi sedang minat juga sedang sebanyak 33 responden dan bila motivasi tinggi, minat belajar juga tinggi sebanyak 33 responden.

Dari hasil penelitian mengenai Hubungan Motivasi Belajar dengan Minat Belajar pada Mahasiswa Tingkat II di Akper Panti Kosala Surakarta menggunakan media kuesioner diperoleh hasil uji dengan $\alpha=$ $5 \%$ (0.05) diperoleh $\mathrm{p}$ sebesar 0.000 sehingga nilai $p<0.05$, yang berarti $\mathrm{Ha}$ diterima sehingga dapat ditarik kesimpulan bahwa ada hubungan antara Motivasi Belajar dengan Minat Belajar pada mahasiswa tingkat II di Akper Panti Kosala Surakarta.

Berdasarkan data di atas maka dapat disimpulkan bahwa bila seseorang memiliki motivasi rendah minatnya juga rendah, bila motivasinya sedang minatnya juga sedang dan bila motivasinya tinggi maka minatnya juga tinggi dan antara motivasi dan minat belajar saling terkait sebagaimana yang diungkapkan oleh Dimyati dan Mudjiono (2006), bahwa motivasi mempunyai kaitan yang erat dengan minat siswa yang memiliki minat terhadap suatu bidang ilmu tertentu cenderung tertarik perhatiannya dan timbul motivasinya untuk mempelajari bidang studi tersebut. Hal tersebut juga sesuai dengan yang diungkapkan oleh Usman (1995), bahwa minat belajar besar sekali pengaruhnya terhadap hasil belajar sebab dengan minat seseorang akan termotivasi melakukan sesuatu yang diminatinya. Jadi bila ingin mahasiswa Akper Panti Kosala terus mampu mencapai hasil belajar yang baik harus terus memacu minat belajarnya agar termotivasi melakukan proses belajar sesuai yang diminatinya.

\section{KESIMPULAN DAN SARAN}

1. Kesimpulan

a. Pada mahasiswa Akademi Keperawatan Panti Kosala Surakarta yang mempunyai motivasi belajar tinggi 47 responden $(48,45 \%), 48$ responden $\quad(49,48 \%)$ mempunyai motivasi belajar yang sedang, dan 2 responden (2,06\%) mempunyai motivasi belajar yang rendah.

b. Pada mahasiswa Akademi Keperawatan Panti Kosala Surakarta yang mempunyai minat belajar tinggi sebanyak 45 responden $(46,39 \%), \quad 49$ responden $(50,52 \%)$ mempunyai minat belajar sedang, 3 responden (3,09\%) mempunyai minat belajar rendah. 
c. Pada uji chi square didapatkan hasil $p=0,00$ (probabilitas < 0,05 ) sehingga Ha diterima, yang berarti ada hubungan yang signifikan antara motivasi belajar dengan minat belajar pada mahasiswa tingkat II di Akper Panti Kosala Surakarta, karena besarnya hubungan 0,866 atau $86,6 \%$ dilihat dari nilai contingency coefficient.

2. Saran

a. Bagi Pendidik

Diharapkan

mampu

mengembangkan mutu proses pembelajaran, baik media ataupun sarana penunjang yang lain khususnya yang berkaitan dengan peningkatan motivasi dan minat belajar. Agar mahasiswa dapat memiliki motivasi yang lebih tinggi terhadap pembelajaran.

b. Bagi Peneliti Berikutnya Diharapkan untuk melakukan penelitian berikutnya tentang motivasi dan minat belajar.

c. Bagi Mahasiswa Akademi Keperawatan Panti Kosala Surakarta

Diharapkan dapat menjadi pegangan dan pedoman bagi mahasiswa untuk meningkatkan minat serta motivasi dalam proses pembelajaran di Akademi Keperawatan Panti Kosala Surakarta.

\section{DAFTAR PUSTAKA}

Dimyanti dan Mudjiono. Belajar dan Pembelajaran. Jakarta: PT. Rineka Cipta, 2006.

Hidayat, Aziz Alimul. Metodologi Penelitian Keperawatan dan Teknik Analisis Data. Jakarta: Salemba Medika, 2008.

.Metodologi Penelitian

Keperawatan dan Teknik Analisis Data. Jakarta: Salemba Medika, 2009.

Purwanto. Psikologi Perilaku. Jakarta: CV. Pustaka Setia, 1998.

Riwidikdo, Handoko. Statistik untuk Penelitian Kesehatan dengan Aplikasi Program $R$ dan SPSS. Yogyakarta : Pustaka Rihama, 2009.

Sobur, Alex. Psikologi Umum Dalam Lintasan Sejarah . Bandung : CV Pustaka Setia, 2010.

Suciati dan Prasetyo Irawan. Teori Belajar dan Motivasi. Jakarta: PAU-PPAI, Universitas Terbuka, 2001.

Sunaryo. Psikologi untuk Keperawatan. Jakarta: EGC, 2004

Suyanto. Metodologi dan Aplikasi Penelitian Keperawatan. Yogyakarta: Nuha Medika, 2011.

\footnotetext{
Dosen AKPER Panti Kosala

Surakarta

2 Dosen AKPER Panti Kosala

Surakarta

3 Mahasiswa AKPER Panti

Kosala Surakarta
} 